\title{
Artikel
}

\section{Online tussenhandelaren: transparantie en eerlijkheid als geboden}

Mr. drs. J.H.M. Spanjaard*

\section{Inleiding}

Op het moment van het schrijven van dit artikel zucht Nederland een jaar onder het coronavirus en de bijbehorende maatregelen. Door de maatregelen - kort gezegd: vooral thuiswerken en in strengere lockdownperiodes de sluiting van horeca en winkels die niet-levensmiddelen verkopen - hebben de online verkoop van roerende zaken en de online dienstverlening een vlucht genomen. Om die reden is het instrument dat in deze bijdrage centraal staat - Verordening (EU) 2019/1150 ter bevordering van billijkheid en transparantie voor zakelijke gebruikers van onlinetussenhandelsdiensten (hierna: de Verordening $)^{1}$ - een nuttige toevoeging aan online verkoop en online dienstverlening. In tegenstelling tot eerdere richtlijnen die op online verkoop van toepassing zijn - onder andere Richtlijn 2011/83 over consumentenovereenkomsten, geimplementeerd in afdeling 6.5.2B van het Burgerlijk Wetboek $(B W)$ - concentreert de Verordening zich niet op consumenten, maar op ondernemers. Dat maakt een bespreking van de Verordening - afgezien van de lettergreeprijke tongbrekers waarmee de Nederlandse taal wordt verrijkt - de moeite waard. De Verordening is op 12 juli 2020 van kracht geworden. ${ }^{2}$

Volgens de Verordening moet de gebruiker van onlinetussenhandelsdiensten beschermd worden, omdat hij als

Mr. drs. J.H.M. Spanjaard is advocaat bij facily LAW advocatuur in Aalsmeer en adviseur bij La Gro Geelkerken Advocaten in Alphen aan den Rijn.

1. PbEU 2019, L 186/57

2. Art. 19 lid 2 van de Verordening. een tussenschakel tussen de onlinetussenhandelsdienstverlener en de consument knel kan komen te zitten. ${ }^{3}$ Onlinetussenhandelsdiensten zijn bijvoorbeeld online marktplaatsen en de mogelijkheid die webwinkels bieden om via de eigen website producten van derde partijen aan te bieden. Door online zoekmachines worden producten van aanbieders zichtbaar voor consumenten.

Die bescherming beoogt de Verordening te bieden door bepalingen te wijden aan de algemene voorwaarden die onlinetussenhandelsdienstverleners en online zoekmachines mogen hanteren en door bepalingen over de rangschikking van zoekresultaten en algoritmes te geven. Daarnaast zet de Verordening in op buitengerechtelijke geschilbeslechting door bemiddelaars. In deze bijdrage worden de bepalingen over algemene voorwaarden en beëindiging in de Verordening besproken en worden daarop gelijkende instrumenten in het Burgerlijk Wetboek en de rechtspraak van de Hoge Raad tegen het licht gehouden.

\section{Inhoud en reikwijdte van de Verordening}

De Verordening is beperkt tot de relatie van onlinetussenhandelsdienstverleners en online zoekmachines met zakelijke gebruikers, waarbij als aanvullende eis geldt dat de zakelijke gebruikers aan consumenten aanbieden. Diensten van onlinetussenhandelsdienstverleners en online zoekmachines aan consumenten en aan zakelijke gebruikers die uitsluitend business-to-business handelen, vallen buiten de reikwijdte van de Verordening.

3. Overweging 5 bij de Verordening. 
De Verordening richt zich op onlinetussenhandelsdiensten en online zoekmachines. De Verordening moet verordeningsautonoom worden uitgelegd en toegepast. Dat betekent dat bij de toepassing en uitleg van bepalingen in de Verordening uitsluitend acht mag worden geslagen op de Verordening en dat de uitleg van begrippen met noties die naar nationaal recht belend zijn, niet is toegelaten. In voorkomende gevallen zal de nationale rechter dan prejudiciële vragen stellen aan de het Hof van Justitie van de Europese Unie. ${ }^{4}$ Dat is goed om in het achterhoofd te houden, omdat er nogal wat termen voorkomen - denk alleen al aan 'algemene voorwaarden', 'duidelijk en begrijpelijk' en 'nietigheid' - die buiten de Verordening ook bestaan en daar een eigen invulling hebben.

Onlinetussenhandelsdiensten zijn volgens artikel 2 onder 2 van de Verordening diensten van de informatiemaatschappij, ${ }^{5}$ die zakelijke gebruikers de mogelijkheid geeft goederen of diensten aan te bieden aan consumenten met het oog op het faciliteren van het initiëren van directe transacties tussen die zakelijke gebruikers en consumenten, ongeacht waar die transacties uiteindelijk worden uitgevoerd, en die op basis van contractsverhoudingen door de onlinetussenhandelsdienstverlener worden geleverd aan zakelijke gebruikers.

De online zoekmachine wordt in artikel 2 onder 5 van de Verordening gedefinieerd als 'een digitale dienst die het gebruikers mogelijk maakt zoekvragen in te voeren om zoekacties uit te voeren op in beginsel alle websites of alle websites in een bepaalde taal, op basis van een zoekvraag over eender welk onderwerp in de vorm van een trefwoord, een gesproken opdracht, een frase of andere input, en die resultaten in eender welk formaat oplevert met informatie over de opgevraagde inhoud'.

De beide begrippen ogen als containerbegrippen. In overweging 11 bij de Verordening maakt de Europese regelgever duidelijker wat hij concreet onder onlinetussenhandelsdiensten verstaat. Dit zijn online marktplaatsen, appstores en platforms voor sociale media. De Verordening geldt niet voor onlinetussenhandelsdiensten zonder betrokkenheid van zakelijke gebruikers ${ }^{6}$ of business-to-business onlinetussenhandelsdiensten die niet aan consumenten worden aangeboden, online reclametools en online platforms voor het uitwisselen van reclame. Ook de diensten van SEO-dienstverleners - dat zijn dienstverleners die de zoektermen optimaliseren zodat de opdrachtgever hoog in de zoekmachine scoort - ter optimalisatie van zoekmachines en advertentieblockers, waarmee reclame kan worden geblokkeerd, vallen buiten het bereik van de Verordening. Het begrip online zoekmachine wordt verder niet verduidelijkt in de considerans of gedefinieerd in de Verordening. Uitsluitend is bepaald dat het begrip technologie-onafhankelijk moet worden opgevat,

4. Het Hof van Justitie van de Europese Unie wordt hierna ook als Hof of HvJ EU aangeduid.

5. In de zin van Richtlijn 2015/1535, PbEU 2015, L 241/1.

6. Hierbij denk ik aan consumentenplatforms, waar consumenten onderling transacties sluiten zonder dat een zakelijke partij tussenbeide komt. zodat ook gesproken zoekopdrachten onder het bereik van de online zoekmachine vallen.

Wat valt er in de Nederlandse context anno 2021 onder? Gedacht kan worden aan Google en Bing als zoekmachines en Marktplaats, eBay, Amazon en bol.com als onlinetussenhandelsdienstverleners. Dan heb ik niet zozeer het oog op de producten die de beide webwinkels zelf verkopen, maar op de mogelijkheid die zij bieden aan handelaren om via hun platform handel te drijven. Ook dienstverleners als booking.com en vliegwinkel.nl vallen wat mij betreft onder het begrip onlinetussenhandelsdienstverlener. Online dienstverleners als AirBNB en Homeaway vallen in de schaduwzone, aangezien daar vooral peer-to-peer woningen te huur lijken te worden aangeboden. Voor de peer-to-peer diensten vallen zij naar mijn mening buiten de Verordening, maar voor zover zakelijke aanbieders via hun platform actief mogen zijn, vallen ze erbinnen. Dat zal betekenen dat de onlinetussenhandelsdienstverleners met een gemengde clientèle er goed aan doen de eisen in de Verordening te volgen. Diezelfde terughoudendheid voel ik overigens ook jegens Marktplaats en eBay, omdat dat platforms zijn waarop zowel business-to-consumer als peer-to-peer goederen worden aangeboden. De platforms worden ook veel door consumenten gebruikt die hun al dan niet overbodige inboedel willen slijten. Ik denk dat de term 'zonder betrokkenheid van zakelijke gebruikers' zou moeten worden geinterpreteerd als 'zonder enige betrokkenheid'.

Daarbij speelt dan nog als complicatie dat het onderscheid tussen de zakelijke gebruiker en de consument niet altijd even eenvoudig te trekken valt. Het komt dan onder meer aan op het toetsen van onderwerpen als:

- de al dan niet georganiseerde wijze van de verkoop;

- winstoogmerk;

- of de verkoper beschikt over informatie en technische vaardigheden waarover de consument niet noodzakelijk beschikt;

- de rechtsvorm van de verkoper en met name of die hem in staat stelt handelsdaden te stellen;

- verband met de commerciële of beroepsmatige activiteit van de verkoper;

- btw-plichtigheid;

- of de verkoper die optreedt namens of voor rekening van handelaren een vergoeding of een deel van de winst ontvangt;

- de inkoop van tweedehands of nieuwe goederen voor de verkoop, waardoor de verkoopactiviteit met een zekere regelmaat, frequentie en/of gelijktijdig met de commerciële beroepsactiviteit plaatsvindt;

- het type en de waarde van de te koop aangeboden producten, met name of ze allemaal van hetzelfde type zijn of dezelfde waarde hebben, en in het bijzonder of het aanbod is geconcentreerd op een beperkt aantal producten. ${ }^{7}$

7. HvJ EU 4 oktober 2018, ECLI:EU:C:2018:808, NJ 2019/234, m.nt. Verkade (Kamenova). Hierover ook M.Y. Schaub, Wie is handelaar?, TvC 2019/1, p. 5-13. 


\section{Algemene voorwaarden}

\subsection{Afbakening algemene voorwaarden}

Algemene voorwaarden zijn volgens de Verordening 'alle voorwaarden of specificaties, ongeacht de benaming of vorm ervan, die van toepassing zijn op de contractverhouding tussen de onlinetussenhandelsdienstverlener en zijn zakelijke gebruikers, die eenzijdig door de onlinetussenhandelsdienstverlener worden bepaald, waarbij die eenzijdige bepaling zal worden vastgesteld op basis van een algemene beoordeling, waarbij de relatieve omvang van de betrokkenen, het feit dat onderhandelingen hebben plaatsgevonden, of dat sommige bepalingen het voorwerp van dergelijke onderhandelingen waren en door de betrokken aanbieder en zakelijke gebruiker samen werden vastgesteld, op zichzelf niet doorslaggevend zijn'. ${ }^{8}$

De definitie van algemene voorwaarden wijkt op een belangrijk onderdeel af van de Nederlandse wet. Artikel 6:231 onder a BW definieert algemene voorwaarden als één of meer bedingen die zijn opgesteld om in meerdere overeenkomsten te worden gebruikt. In Nederland staan dus puur de bestemming en het repetitieve karakter centraal. De Verordening stelt niet de eis dat de algemene voorwaarden in meerdere overeenkomsten worden gebruikt. De Verordening lijkt veel meer aan te haken bij de norm die ook in Richtlijn 93/13 (Oneerlijke bedingen in consumentenovereenkomsten) is neergelegd: over het beding is niet onderhandeld.

Een tweede wezenlijke wijziging is dat de algemene voorwaarden volgens de Verordening gedurende het hele contracteerproces beschikbaar moeten zijn, ook in de precontractuele fase. Naar Nederlands recht moeten de algemene voorwaarden op zijn laatst bij gelegenheid van het sluiten van de overeenkomst, althans - indien geen schriftelijke overeenkomst wordt gesloten - bij anvang van uitvoering van de dienst, beschikbaar worden gesteld. ${ }^{9}$

\subsection{Transparantie-eis en de Richtlijn Oneerlijke bedingen}

De onlinetussenhandelsdienstverlener moet algemene voorwaarden hanteren die duidelijk en begrijpelijk zijn opgesteld. Daaronder verstaat de Verordening dat ze niet misleidend, niet vaag, voldoende specifiek en voldoende gedetailleerd zijn over belangrijke commerciële kwesties, en dat zij zakelijke gebruikers bijgevolg geen redelijke mate van voorspelbaarheid verschaffen over de belangrijkste aspecten van de contractsverhouding. Met name dit laatste argument intrigeert, omdat de voorspelbaarheid ondubbelzinnig onderdeel van de duidelijkheid en begrijpelijkheid wordt gemaakt.

8. Art. 2 onder 10 van de Verordening.

9. Art. 6:230e BW. Vgl. voor niet-dienstverrichters: art. 6:234 lid 1 en 2 BW. Hierbij zij bedacht dat ook in geval van wijziging kennis moet worden gegeven van de gewijzigde algemene voorwaarden om de toepasselijkheid te waarborgen en aan vernietiging te ontkomen.
De term 'duidelijk en begrijpelijk' is bekend uit Richtlijn 93/13 (Oneerlijke bedingen in consumentenovereenkomsten). Deze norm is ontleend aan artikel 5 van genoemde richtlijn. Volgens dit artikel moeten bedingen niet alleen grammaticaal en juridisch duidelijk zijn, maar ook economisch duidelijk zijn. ${ }^{10}$ Pavillon geeft aan dat de maatstaf is of een normaal geinformeerde en redelijk omzichtige en oplettende gemiddelde consument het beding economisch kan doorgronden. ${ }^{11}$

Met dit laatste bedoelt het HvJ EU dat de consument bij het aangaan van de overeenkomst moet weten aan welke financiële verplichtingen hij zich verbindt, zodat hij weloverwogen de keuze kan maken of het aangaan van de overeenkomst voor hem gunstig is. Op de schending van deze (precontractuele) informatie- en transparantieplicht staat geen aparte sanctie. Pavillon merkt terecht op dat de informatie- en transparantieplicht onderdeel vormt van de toets aan de in artikelen 3 en 5 van Richtlijn 93/13 gestelde eisen van goede trouw, evenwicht en transparantie. Ook in het Kásler-arrest werd de transparantieverplichting aan de oneerlijkheidstoets gekoppeld. ${ }^{12}$ Transparantie wordt dus niet apart gesanctioneerd, maar vormt een gezichtspunt in de oneerlijkheidstoets. ${ }^{13}$ Deze oneerlijkheidstoets ontbreekt in de Verordening. Het is niet duidelijk of dit betekent dat onduidelijkheid in de voorwaarden direct tot nietigheid leidt. Als dat het geval is, dan is de toets onder de Richtlijn Oneerlijke bedingen strenger dan die onder de Verordening.

Op grond van artikel 3 lid 1 van Richtlijn 93/13 wordt een beding in een overeenkomst als oneerlijk beschouwd, indien (a) niet afzonderlijk over het beding is onderhandeld en (b) het beding, in strijd met de goede trouw, het evenwicht tussen de uit de overeenkomst voortvloeiende rechten en verplichtingen van de partijen ten nadele van de consument aanzienlijk verstoort. De ratio is dat de consument beschermd dient te worden, omdat hij zich in een zwakke positie bevindt ten opzichte van de professional, die over meer informatie beschikt. Daarom moet het beginsel van transparantie ruim worden opgevat. ${ }^{14}$

Mij komt op basis van overweging 15 van de Verordening - duidelijkheid en begrijpelijkheid moeten de voorspelbaarheid van de zakenrelatie bevorderen; de Verordening noemt niet de drie elementen uit Richtlijn $93 / 13$ en evenmin de noodzaak van duidelijkheid en begrijpelijkheid voor het nemen van de beslissing om de overeenkomst al dan niet aan te gaan - voor dat de norm een minder strenge zou moeten zijn dan die onder Richtlijn 93/13, maar het woord hierover is aan het $\mathrm{HvJ}$ EU.

10. Zie o.a. C.M.D.S. Pavillon, Wat maakt een beding oneerlijk? Het Hof wijst ons (eindelijk) de weg, TvC 2014/4

11. C.M.D.S. Pavillon, Materieelrechtelijke beschouwingen naar aanleiding van de tweede gratis-mobieltjes-uitspraak van de Hoge Raad, TvC 2016/5, p. 240

12. HvJ EU 30 april 2014, C-26/13, NJ 2014/355, m.nt. MRM (Kásler).

13. Pavillon 2014 , p. $168-170$

14. HvJ EU 23 april 2015, C-96/14, n.n.g. (Van Hove/CNP), r.o. 40-41. Vgl. voorts HvJ EU 9 juli 2015, C-348/14, n.n.g. (Bucura/Bancpost), r.o. 51-60. 
Daarnaast bepaalt de Verordening dat de algemene voorwaarden eenvoudig beschikbaar moeten zijn, ook al in de precontractuele fase. Ook moeten algemene voorwaarden ten aanzien van beëindiging van diensten de redenen daarvoor bevatten, of de redenen voor het besluit tot volledige of gedeeltelijke oplegging van enige andere beperking aan de verstrekking van hun onlinetussenhandelsdiensten aan zakelijke gebruikers. Tot slot moeten de algemene voorwaarden informatie geven over de distributiekanalen en de eigendom en controle van intellectuele-eigendomsrechten van de zakelijke gebruikers. In geval van wijziging van de algemene voorwaarden geldt dat de wijzigingen op een duurzame gegevensdrager ter beschikking worden gesteld en dat de zakelijke gebruiker het recht heeft de relatie met inachtneming van een opzegtermijn van vijftien dagen te beëindigen. Deze normen gaan verder dan die voor consumenten, waarvoor onder artikelen 6:233 6:230c BW dergelijke eisen nog niet gelden.

Een duurzame gegevensdrager is 'een hulpmiddel dat zakelijke gebruikers in staat stelt persoonlijk aan hen gerichte informatie op te slaan op een wijze die deze informatie toegankelijk maakt voor toekomstig gebruik gedurende een periode die is afgestemd op de doelstellingen waarvoor de informatie kan dienen, en die een ongewijzigde reproductie van de opgeslagen informatie mogelijk maakt'. ${ }^{15}$ In het Content Services-arrest verduidelijkte het HvJ EU al dat onder 'duurzame gegevensdrager' onder meer kunnen worden verstaan: brief, fax, harde schijven, cd-rom, dvd-rom, USB-stick en platte tekst in een e-mail. ${ }^{16}$ Een hyperlink in een e-mail, een publicatie op een website of een dashboard op een website voldoet niet aan de kwalificatie van de duurzame gegevensdrager. Het is de vraag of het Content Services-arrest ook in deze situatie kan worden toegepast, gelet op de verordeningsautonome interpretatie van de Verordening, maar de norm lijkt mij toepasbaar, omdat in Content Services en in de Verordening hetzelfde doel wordt nagestreefd met de duurzame gegevensdrager: het ongewijzigd kunnen opslaan en reproduceren van gegevens.

Volgens de Verordening is nietigheid de sanctie indien algemene voorwaarden niet aan deze eisen voldoen. Het is de vraag hoe de nietigheid moet worden uitgelegd. De term 'nietigheid' komt voor in artikel 101 lid 2 van het Verdrag betreffende de werking van de Europese Unie (VWEU), waar de sanctie op (onder andere) overeenkomsten die de mededinging beperken, luidt dat zij van rechtswege nietig zijn. ${ }^{17}$

In Nederland zou eerder aan de sanctie vernietiging worden gedacht, omdat de bescherming slechts tot een

15. Art. 2 onder 13 van de Verordening. Onduidelijk is of hieronder hetzelfde wordt verstaan als onder de 'duurzame gegevensdrager' in he Content Services-arrest dat in de volgende voetnoot wordt besproken.

16. HvJ EU 5 juli 2012, ECLI:EU:C:2012:419 (Content Services), r.o. 42. Dit arrest ging over de vraag of een handelaar aan zijn informatieplichten uit hoofde van Richtlijn 97/7 (Consumentenkoop op afstand) had voldaan door de gegevens in een hyperlink te verstrekken. Het Hof beantwoordde de vraag ontkennend omdat een hyperlink geen duurzame gegevensdrager is.

17. Vgl. ook art. $6 \mathrm{Mw}$. van de partijen beperkt is. Procesrechtelijk maakt het groot verschil: vernietiging kan slechts worden uitgesproken indien de benadeelde partij - in dit geval de zakelijke gebruiker - vernietigt of vernietiging vordert. Nietigheid moet door de rechter ambtshalve worden toegepast. Volgens de Verordening moet de nietigheid ex tunc en erga omnes werken. ${ }^{18}$ Met name die werking ten opzichte van allen dwingt meer richting 'nietigheid', omdat vernietiging naar Nederlands recht hoofdzakelijk relatief werkt. ${ }^{19}$ De vraag is of het HvJ EU over de Verordening zal oordelen dat deze ambtshalve getoetst moet worden. Die stap heeft het Hof wel gezet ten aanzien van de Richtlijn 93/13 (Oneerlijke bedingen in consumentenovereenkomsten), Richtlijn 99/44 (Conformiteit bij consumentenkoop) en de Colportagerichtlijn. De ratio achter ambtshalve toetsing is steeds dat de consumentenbescherming dermate belangrijk is dat de consument beschermd moet worden, desnoods tegen zijn eigen rechtsbijstandsverlener. De normadressaat van de Verordening is evenwel de zakelijke gebruiker, een ondernemer. Ik denk daarom niet dat de verplichtingen uit de Verordening zo ver gaan dat de rechter algemene voorwaarden onder de Verordening ambtshalve moet toetsen. ${ }^{20}$ Het woord hierover is evenwel aan het HvJ EU.

De algemenevoorwaardenregeling in de Verordening is, anders dan afdeling $6.5 .3 \mathrm{BW}$, niet beperkt tot kleine en zuiver nationale partijen. ${ }^{21}$

\subsection{Transparantie-eis en artikel 6:233 onder a BW}

Op het gebied van algemene voorwaarden gaat de Verordening verder dan de Nederlandse wet. De Nederlandse wet bepaalt, buiten het voor consumentwederpartijen geldende artikel 6:238 lid $2 \mathrm{BW}$, niet dat algemene voorwaarden duidelijk en begrijpelijk moeten zijn opgesteld. Dit komt doordat afdeling 6.5.3 BW zich richt op de vraag of algemene voorwaarden onredelijk bezwarend zijn. Daarbij kan rekening worden gehouden met de duidelijkheid en begrijpelijkheid, maar dat is slechts een van de vele omstandigheden in het gezichtspuntenmandje van artikel 6:233 onder a $B W .^{22}$ In de Nederlandse rechtssfeer is de nadruk in de rechtspraak onder afdeling 6.5.3. BW vooral op de consumenten komen te liggen. $\mathrm{Zij}$ worden geholpen door de zwarte en grijze lijsten van de artikelen 6:236 en 6:237 BW, die invulling geven aan de open norm van artikel 6:233 onder a BW. Voor zakelijke wederpartijen ontbreken dergelijke lijsten en zij zullen van geval tot geval moeten aantonen waarom het beding in kwestie onredelijk bezwarend is.

Op de wederpartij rust namelijk in beginsel de stelplicht en bewijslast van zijn stelling dat het beding onredelijk

18. Overweging 20 bij de Verordening. Vgl. ook HvJ EU 26 april 2012, TvC 2012/6, m.nt. J.H.M. Spanjaard, p. 279-284 (Invitel).

19. Art. 3:40 lid 2 BW.

20. Zie ook A.G.F. Ancery \& C.M.D.S. Pavillon, Processuele aspecten van reflexwerking van consumentenrecht, WPNR 2014/7026, p. 647-655.

21. Art. 6:235 lid 1 BW en art. 6:247 lid 2 BW.

22. Vgl. ook HR 22 november 2019, ECLI:NL:HR:2019:1830 (ABN AMRO/SdB en Euribar). 
bezwarend is. ${ }^{23}$ Indien de wederpartij niet slaagt in haar stelplicht, wordt het beroep op vernietiging van de algemene voorwaarde in kwestie afgewezen. ${ }^{24}$

Het komt bij de inhoudstoetsing van een beding aan op de vraag of het beding onredelijk bezwarend is voor de individuele wederpartij. De mate van bezwarendheid wordt niet objectief, maar binnen de contractuele verhouding veeleer subjectief vastgesteld. Bij de toetsing van onredelijk bezwarendheid van een beding speelt niet direct een rol welk soort nadeel de wederpartij heeft geleden. Niet vereist is dat het nadeel van financiële aard is.

Het vernietigen van algemene voorwaarden is in de rechtspraak vooral voorbehouden voor consumenten, waarin - mede aangejaagd door de ambtshalve toetsing van algemene voorwaarden onder vigeur van Richtlijn 93/13 (Oneerlijke bedingen in consumentenovereenkomsten - geregeld bepalingen in algemene voorwaarden sneuvelen. ${ }^{25}$ Hoewel artikel 6:233 onder a BW ook op business-to-small-business ${ }^{26}$ van toepassing is, wordt de vernietiging van algemene voorwaarden in zakelijke overeenkomsten op de voet van artikel 6:233 onder a BW nauwelijks uitgesproken. ${ }^{27}$ Het verrassende karakter van het beding - waar de Verordening enigszins de nadruk op lijkt te leggen - lijkt naar Nederlands recht amper een rol te spelen.

\subsection{Verrassende bedingen en duidelijkheid en begrijpelijkheid}

Naar Nederlands recht is de verrassendheid van het beding een omstandigheid die getoetst kan worden op de voet van het Holleman/De Klerk-arrest. ${ }^{28}$ In dit arrest oordeelde de Hoge Raad, zakelijk weergegeven:

1. Aan in het handelsverkeer tussen ondernemingen bedingen van de toepasselijkheid van algemene voorwaarden behoren geen andere eisen te worden gesteld dan in het algemeen gelden voor het tot stand komen van een overeenkomst.

23. HR 21 september 2012, NJ 2013/431 (Van Marrum/Wolff).

24. Vgl. o.a., als kleine greep uit een lijst van ruim honderd inhoudelijke uitspraken, Hof Den Haag 6 september 2016, ECLI:NL:GHDHA: 2016:2509, NJF 2016/427; Hof Arnhem-Leeuwarden 15 november 2016, ECLI:NL:GHARL:2016:9109; Hof Arnhem-Leeuwarden 27 december 2016, ECLI:NL:GHARL:2016:10514 (Janse/Kampstaal); Hof 's-Hertogenbosch 29 november 2016, ECLI:NL:GHSHE:2016:5311 (Continental/Accountant); Hof 's-Hertogenbosch 22 november 2016, ECLI:NL:GHSHE:2016:5210; Hof Arnhem-Leeuwarden 8 november 2016, ECLI:NL:GHARL:2016:8953 (X/Rabobank); Rb. Rotterdam 2 november 2016, ECLI:NL:RBROT:2016:8111 (Orcem/Walco); Rb. Amsterdam 21 september 2016, ECLI:NL:RBAMS:2016:5825, NTHR 2016/6, p. 329 (X/ING); Hof Den Haag 26 april 2016, ECLI:NL:GHDHA:2016:2018, WR 2016/153 (Corfu/Ypenburg); Hof Amsterdam 19 april 2016, ECLI:NL:GHAMS:2016:1548.

25. Voor een overzicht o.a. J.H.M. Spanjaard, Kroniek algemene voorwaarden 2015-2016, TvC 2016/6, p. 273-284; J.H.M. Spanjaard, In de kern duidelijk: de toetsing van kernbedingen, ORP 2017/41; J.H.M. Spanjaard, Reflecteren op de reflexwerking, ORP 2017/101; J.H.M. Spanjaard, Schuld en boete in het ambtshalve consumentenrecht, ORP 2018/66.

26. Afgebakend door art. 6:235 lid 1 BW en art. 6:247 lid 2 BW.

27. Zie ook Spanjaard 2017. Zie ook de in voetnoot 15 aangehaalde uitspraken.

28. HR 20 november 1981, NJ 1982/517 (Holleman/De Klerk). Zie ook HR 1 juli 1993, NJ 1993/688 (Bouma/Cavo).
2. Het voorkomen van een exoneratiebeding in de algemene voorwaarden maakt dat niet anders.

3. Dat toepasselijkheid van algemene voorwaarden aldus overeengekomen is, sluit niet uit dat er zich onder die voorwaarden bepalingen bevinden van een zodanige inhoud dat de toestemming van de wederpartij niet kan worden geacht op toepasselijkverklaring ook daarvan gericht te zijn geweest.

4. Of dit het geval is, is een kwestie van uitleg van de overeenkomst.

Bedacht dient te worden dat het arrest Holleman/De Klerk is gewezen onder het oude Burgerlijk Wetboek, toen afdeling 6.5.3 BW nog niet gold. Aangenomen wordt dat het Holleman/De Klerk-arrest niet geldt voor algemene voorwaarden waarop afdeling $6.5 .3 \mathrm{BW}$ van toepassing is. Dit wordt afgeleid uit artikel 6:232 BW. ${ }^{29}$ Het arrest heeft wel nog waarde voor bedingen die geen algemene voorwaarde zijn en - naar mijn mening - voor buitenlandse professionele wederpartijen, omdat afdeling 6.5.3 BW op grond van artikel 6:247 lid 2 BW op hen niet van toepassing is.

Waar de stelling 'dit beding is verrassend en daardoor onredelijk bezwarend' wordt betrokken, zal de wederpartij moeten stellen en bewijzen waarom het beding verrassend is. Dit zal de wederpartij in de regel kunnen doen door aan te geven wat gebruikelijk is in de branche waarvan de wederpartij onderdeel uitmaakt. Aan de hand van die branchegebruiken kan vervolgens worden afgewogen of de wederpartij het betreffende beding gelet op haar eigen branche-ervaring kon en moest verwachten. Ook kan de wederpartij stellen en bewijzen dat het beding ongebruikelijk is, omdat het in de branche van de gebruiker zelf ongebruikelijk is. Dit argument zal met name gevoerd worden, stel ik mij voor, indien de wederpartij aan meerdere branchegenoten van de gebruiker offerte heeft gevraagd. Overigens kan ook de gebruiker het verweer voeren dat zijn voorwaarden gebruikelijk zijn en dat de wederpartij dat bij enige oriëntatie ook wel had geweten. Dan zal de gebruiker moeten stellen dat zijn algemene voorwaarden gebruikelijk zijn in de branche, dat op de wederpartij een onderzoeksplicht rust en dat zij bij het uitvoeren van dat onderzoek nimmer verrast zou kunnen zijn.

De uitspraken waarin algemene voorwaarden verrassend en daardoor onredelijk bezwarend worden beoordeeld, zijn op de vingers van één hand te tellen. Verrassendheid speelt met name een rol waar derden de overeenkomst ingezogen worden. In het vonnis Hoist/Breuer van de rechtbank Alkmaar d.d. 7 september 2009 werd een vervalbeding in verband met het overlijden van de wederpartij onredelijk bezwarend geacht. ${ }^{30}$ Ook een automatisch verlengingsbeding werd onredelijk bezwarend geacht in de zaak Vitrina van de rechtbank Den

29. Vgl. R.H.C. Jongeneel, Begrijpt u wat u niet leest?, TvC 2019/2, p. 82 met verdere verwijzingen.

30. Rb. Alkmaar 7 september 2009, ECLI:NL:RBALK:2009:BK1080 (Hoist/ Breuer). 
Haag van 26 augustus 2009. ${ }^{31}$ In de zaak van rechtbank Amsterdam van 27 oktober 2010 werd een hoofdelijkheidsbeding verrassend geacht, en daarmee onredelijk bezwarend. ${ }^{32}$ Ook vervalbedingen staan nog wel eens op de verdachtenlijst, aldus het hof Amsterdam van 11 december 2012 in de zaak Primera/Alvira, waarin een vervalbeding onredelijk bezwarend werd geacht. ${ }^{33}$ In de zaak van American Express werd een hoofdelijkheidsbeding door de rechtbank Noord-Nederland op 6 februari 2013 verrassend en daarmee onredelijk bezwarend geacht. ${ }^{34}$ In de hoofdelijkheidszaak gaat het om clausules die bepalen dat naast de contractspartner de directeur van de contractspartner hoofdelijk aansprakelijk is voor nakoming van de verplichtingen uit de overeenkomst. Voor het overige lijkt de verrassendheid van het beding geen rol te spelen. Dit signaleerde ook Pavillon in haar bijdrage in WPNR waarin zij kort ingaat op de rol die verrassende bedingen onder het huidige recht hebben. ${ }^{35} \mathrm{Zij}$ spoorde een handjevol uitspraken op waarin verrassendheid een rol speelde. ${ }^{36} \mathrm{Zij}$ signaleert dat het lastig is het criterium 'het beding is verrassend' in de inhoudstoetsing van artikel 6:233 onder a BW te toetsen. Daarbij speelt met name artikel 6:232 BW, dat de wederpartij gebonden acht aan ook niet-gekende algemene voorwaarden, een rol.

\subsection{Koppeling Verordening en verrassende bedingen?}

Wellicht kan de norm uit de Verordening de brug slaan tussen afdeling 6.5.3 BW en de doctrine in het Holleman/De Klerk-arrest. Met name de voorspelbaarheid die de Verordening onder de duidelijkheid en begrijpelijkheid eist, triggert daarin. Onder de Verordening zal van de (Nederlandse) rechters in business-to-businessverhoudingen een andere benadering worden verwacht. $\mathrm{Zij}$ moeten indringender toetsen of het beding voldoende transparant is en door de wederpartij begrepen kon worden. Daarbij zullen bedingen meer tegen het licht worden gehouden dan thans in de Nederlandse rechtspraak wellicht het geval is.

Wellicht vormt de Verordening de opmaat voor een algemenevoorwaardenregeling in het Burgerlijk Wetboek waarin meer gefocust wordt op duidelijkheid en begrijpelijkheid, ook in het zakelijk verkeer. De argumenten die de Europese regelgever in de Verordening noemt - te weten: het bepalen van de

31. Rb. Den Haag 26 augustus 2009, ECLI:NL:RBSGR:2009:BJ5556 (Vitrina/X).

32. Rb. Amsterdam 27 oktober 2010, ECLI:NL:RBAMS:2010:BP7523 (Paysquare/A).

33. Hof Amsterdam 11 december 2012, ECLI:NL:GHAMS:2012:BZ1996 (Primera/Alvira).

34. Rb. Noord-Nederland 6 februari 2013, ECLI:NL:RBNNE:2013:BZ8184 (American Express/X).

35. C.M.D.S. Pavillon, De aanpak van verrassende bedingen onder het nieuw BW: de mazen van afdeling 6.5.3 inzake algemene voorwaarden, WPNR 2017/7133, p. 53-60.

36. Rb. Rotterdam 29 augustus 2012, ECLI:NL:RBROT:2012:BX6646; Rb. Zutphen 23 november 2011, ECLI:NL:RBZUT:2011:BU6771; Hof Arnhem 4 maart 1997, NJ 1998/732. Daarnaast vond ik - meer indirect Hof Den Bosch 18 december 2012, ECLI:NL:GHSHE:2012:BY7132 $(\mathrm{SPH} / \mathrm{X})$. commerciële voorwaarden van de onlinetussenhandelsdiensten en het waarborgen van de voorspelbaarheid van de zakenrelatie - spreken mij aan en acht ik redelijke uitgangspunten ook onder het Nederlandse contractenrecht en de contracteervrijheid. In de arresten Baris/ Riezenkamp en Vodafone/ETC ligt naar mijn mening geen andere grondgedachte besloten. ${ }^{37}$ De wetgever zou voor inspiratie in de Verordening kunnen kijken, of uit het Belgische recht artikel VI.91.2 van het Wetboek Economisch recht over kunnen nemen, die beide over duidelijkheid en begrijpelijkheid gaan. Op die manier kan het handelsverkeer in Nederland worden verbeterd en ook het doel van artikel 6:233 onder a BW - het tegengaan van onereuze bedingen in algemene voorwaarden - meer worden bereikt.

\section{Opzegging}

Artikel 4 van de Verordening gaat over de beperking, opschorting en beëindiging door de onlinetussenhandelsdienstverlener aan de zakelijke gebruiker. Het artikel bepaalt dat indien een onlinetussenhandelsdienstverlener besluit om de levering van zijn onlinetussenhandelsdiensten aan een bepaalde zakelijke gebruiker van individuele door die zakelijke gebruiker aangeboden goederen of diensten te beperken of op te schorten, hij de betrokken zakelijke gebruiker voordat of op het moment dat de beperking of opschorting ingaat, een motivering van dat besluit op een duurzame gegevensdrager verstrekt. Indien hij de relatie volledig beëindigt, geldt daarbij een aankondigingstermijn van dertig dagen.

Overweging 22 bij de Verordening maakt duidelijk waarom de reden moet worden gegeven: de zakelijke gebruiker kan aan hand van de motivering beoordelen of hij zich moet verweren tegen de opzegging. Daarbij geeft diezelfde overweging aan dat ervan wordt uitgegaan dat de opzeggingsgronden in de algemene voorwaarden zijn opgenomen. Dit zal er naar mijn mening toe leiden dat de opzeggingsbepalingen in de algemene voorwaarden belangrijk worden en dat met uitgebreide bepalingen over de beëindiging van overeenkomsten zal worden gewerkt, waarin werkelijk voor ieder anker wordt gelegen. Hierbij kan gedacht worden aan de gangbare riedel dat opzegging mogelijk is (1) met het in acht nemen van een bepaalde termijn zonder opzeggingsgrond en (2) met onmiddellijke ingang bij bijvoorbeeld (a) tekortschieten door de andere partij, (b) insolventie van de andere partij of (c) dreigende reputatieschade door toedoen van de andere partij.

a. De aankondigingstermijn van dertig dagen geldt niet in de volgende, alternatieve gevallen, aldus artikel 4 lid 4 van de Verordening:

a. de onlinetussenhandelsdienstverlener is onderworpen aan een wettelijke of regelgevende verplich-

37. HR 15 november 1957, NJ 1958/67 (Baris/Riezenkamp); HR 19 oktober 2007, ECLI:NL:HR:2007:BA7024 (Vodafone/ETC). 
ting om de verstrekking van het geheel van zijn onlinetussenhandelsdiensten aan een bepaalde zakelijke gebruiker te beëindigen op een manier die hem niet de mogelijkheid biedt deze opzegtermijn in acht te nemen.

b. De onlinetussenhandelsdienstverlener oefent op grond van met Unierecht conforme nationale wetgevingsbepalingen een recht van beëindiging om een dwingende reden uit.

c. De onlinetussenhandelsdienstverlener kan aantonen dat de betrokken zakelijke gebruiker herhaaldelijk de toepasselijke algemene voorwaarden heeft geschonden, wat heeft geleid tot de beëindiging van de levering van het geheel van de betrokken onlinetussenhandelsdiensten.

Overweging 23 bij de Verordening geeft nog wat aanwijzingen bij de toepassing van de (onmiddellijke) beëindiging. De verschillende uitzonderingen op de opzegtermijn van dertig dagen kunnen met name ontstaan bij illegale of ongepaste inhoud, de veiligheid van een goed of dienst, namaak, fraude, malware, spam, inbreuken in verband met de persoonsgegevens, andere cyberbeveiligingsrisico's of de geschiktheid van het goed of de dienst voor minderjarigen, aldus overweging 23. Daarnaast gaat de Verordening uit van zo veel mogelijk delisten (lees: uit het online aanbod verwijderen) van individuele goederen en diensten en wordt volledige beëindiging als een ultimum remedium gezien.

De variant onder a zal zich naar Nederlands recht nauwelijks voordoen. Dit zou kunnen spelen als het wettelijk verboden wordt met bepaalde personen of landen handel te drijven. Het geval onder b laat zich lastig duiden. Wat maakt een reden immers dwingend? Moet het dan gaan om onmogelijkheid van nakoming of om een situatie waarin nakoming lastig gevergd kan worden? De ontbindingsregeling van artikel 6:265 $\mathrm{BW}$ komt mij voor als een met het Unierecht conforme bepaling die het recht op beëindiging geeft. Ook artikel 7:408 lid 2 BW - de relatie tussen de onlinetussenhandelsdienstverlener en de zakelijke gebruiker is naar mijn mening een overeenkomst van opdracht in de zin van artikelen 7:400 e.v. BW - geeft de mogelijkheid van opzegging en lijkt in overeenstemming met het Unierecht.

In de praktijk verwacht ik dat in de praktijk gevalstype c het meest zal worden toegepast. Daar komt het - zoals hiervoor is gesignaleerd - met name aan op de gedetailleerdheid van de algemene voorwaarden en de daarin opgenomen beëindigingsbepaling. Hoe specifieker die is, des te makkelijker zal de beëindiging plaats kunnen vinden. Daarbij kan worden voorgesteld dat de algemene voorwaarden bepalen dat beëindiging bij een 'ernstige tekortkoming' kan plaatsvinden, gevolgd door een definitie van de 'ernstige tekortkoming'. ${ }^{38}$ De in overweging 23 bij de Verordening genoemde omstan-

38. Vgl. HR 28 september 2018, ECLI:NL:HR:2018:1810, NJ 2019/446, m.nt. JH, en AA2019/0293, m.nt. H.N. Schelhaas (Eigen Haard). Vgl. ook de bijdrage van Rijsterborgh over Eigen Haard in deze editie van Contracteren. digheden kunnen daarbij worden genoemd, gevolgd door de volgende, meer generieke gronden:

- tekortkoming in de nakoming van de overeenkomst, die na ingebrekestelling niet wordt hersteld; ${ }^{39}$

- iedere handeling van de zakelijke gebruiker die de goede naam en faam van de onlinetussenhandelsdienstverlener kan beschadigen;

- insolventie, ontbinding of bedrijfsbeëindiging van de zakelijke gebruiker.

Onduidelijkheid bestaat over het begrip 'herhaaldelijk', met name ook omdat het Nederlandse recht de eis van herhaaldelijkheid in artikel 6:265 lid 1 BW en artikel 7:408 BW niet stelt. Hoe vaak moeten de algemene voorwaarden zijn overtreden om van 'herhaaldelijk' te kunnen spreken? Strikt genomen zouden twee overtredingen naar mijn mening als herhaaldelijk kunnen worden beschouwd.

Dient 'herhaaldelijk' zo te worden uitgelegd dat telkens dezelfde bepaling moet zijn overtreden? Naar mijn mening is dat niet het geval. De Verordening noemt generiek 'herhaaldelijke schending van de algemene voorwaarden', waardoor ook overtredingen van telkens een andere bepaling in de algemene voorwaarden aanleiding tot beëindiging kunnen geven.

De verschillen met het Nederlandse recht zijn manifest. De Verordening meent dat de reden voor beëindiging bij een neutrale beëindiging moet worden genoemd op een duurzame gegevensdrager en een opzegtermijn van minstens dertig dagen in acht moet worden genomen. Dit doet naar Nederlands recht denken aan de opzegging van duurovereenkomsten. De onlinetussenhandelsdienstverleningsovereenkomst zal naar Nederlands recht als een overeenkomst van opdracht worden gekwalificeerd. Dat betekent dat, behoudens contractuele uitsluiting, de overeenkomst in beginsel te allen tijde door de opdrachtgever (in dit geval: de zakelijke gebruiker) kan worden opgezegd, aldus artikel 7:408 BW. Het artikel regelt evenwel niets over de opzegtermijn.

Volgens vaste rechtspraak van de Hoge Raad over de opzegging van duurovereenkomsten zonder opzegbepaling kan onder omstandigheden op grond van de aanvullende werking van de redelijkheid en billijkheid ${ }^{40}$ een opzeggingstermijn, een zwaarwegende opzeggingsgrond of schadevergoeding worden geëist, ${ }^{41}$ om zo tegemoet te komen aan de belangen van de wederpartij die zijn bedrijfsvoering moet aanpassen aan de nieuwe situatie. Of deze vereisten in een concreet geval daadwerkelijk moeten worden gesteld, is onder meer afhankelijk van de contractsduur tot het moment van opzegging (was dat van lange duur, dan ligt een opzeggingstermijn voor

39. Dit zou ook onder gevalstype $b$ kunnen vallen.

40. Vgl. Asser/Houben 7-X 2019/131.

41. HR 28 oktober 2011, NJ 2012/685, m.nt. T.F.E. Tjong Tjin Tai (De Ronde Venen/Stedin), waarover o.m. Asser/Houben 7-X 2019/122 e.v.; H.N. Schelhaas, Redelijkheid en billijkheid (Mon. BW nr. A5) 2017/26; T.H. Tanja-van den Broek, Gemeente De Ronde Venen/Stedin C.S.: versoepeling van de mogelijkheden tot opzegging van een duurovereenkomst voor onbepaalde tijd?, MvV 2012/2, p. 18-22; W.L. Valk, Opzegging van duurovereenkomsten na Gemeente/SNU en Stedin, NTBR 2012/25 
de hand), de afhankelijkheid van de opgezegde partij van het contract, de gedane investeringen die bij voortduring van het contract zouden zijn terugverdiend, en de omstandigheid dat tijd en kosten zijn gemoeid met het omschakelen naar een nieuwe bedrijfsvoering na opzegging. ${ }^{42}$ Dit zijn eisen die de Verordening niet stelt. Hierin wijkt het Nederlandse recht dus wezenlijk af van de Verordening, omdat de Verordening én een opzegtermijn én een motivering eist. ${ }^{43}$ Omdat de Verordening voorgaat, zal het Nederlandse recht op dit punt moeten wijken.

De motivering - en naar ik proef: de opzegging - moeten op schrift zijn gesteld. Die eis wordt naar Nederlands recht niet gesteld. De opzegging is naar Nederlands recht vormvrij, wat inhoudt dat zij ook mondeling kan plaatsvinden en zelfs uit gedragingen kan blijken. ${ }^{44}$ Verder meent de Verordening dat de opzegging zo veel mogelijk partieel moet plaatsvinden - het delisten van bepaalde producten - en dat volledige opzegging de uitzondering moet zijn. Naar Nederlands recht wordt dat onderscheid niet gemaakt en gaat het in de rechtspraak vrijwel uitsluitend over volledige opzegging van de overeenkomst. De leerstukken vernietiging en ontbinding kennen wel de mogelijkheid partieel te vernietigen of te ontbinden. ${ }^{45}$

\section{Afronding}

Sinds 12 juli 2020 geldt EU-Verordening 2019/1150 over onlinetussenhandelsdiensten. Deze Verordening brengt nogal wat wijzigingen voor het gebruik en de omgang met contracten mee voor onlinetussenhandelsdienstverleners en hun klanten. Deze wijzigingen wijken met name op het gebied van de opzegging van overeenkomsten en de inhoud en omgang met algemene voorwaarden op wezenlijke punten af van het Burgerlijk Wetboek. De Verordening is dus een instrument dat exploitanten en adviseurs van onlinetussenhandelsdiensten in hun kennisrugzak moeten hebben.

Wat betreft de algemenevoorwaardenbepaling, en dan met name de eis dat algemene voorwaarden duidelijk en begrijpelijk moeten zijn om voorspelbaarheid in de zakenrelatie te waarborgen, meen ik dat de Verordening tot inspiratie kan dienen voor de Nederlandse wetgever.

42. Zie nader Schelhaas 2017.

43. Zie o.a. HR 28 oktober 2011, NJ 2012/685, m.nt. T.F.E. Tjong Tjin Tai (De Ronde Venen/Stedin), waarin de Hoge Raad oordeelde dat opzegging in beginsel zonder meer mogelijk is zonder dat een zwaarwegende reden van opzegging hoeft te worden genoemd. Mijns inziens suggereert de Hoge Raad dat ook zonder motivering opgezegd kan worden. Dit verhoudt zich ook met art. 7:408 BW, dat een opzeggingsmogelijkheid 'te allen tijde' biedt. Daarbij past niet dat de opdrachtgever, die te allen tijde mag opzeggen, wel nog een reden voor opzegging moet geven.

44. Art. 3:37 lid 1 BW. Vgl. ook HR 1 juni 2018, ECLI:NL:HR:2018:819, waarin de mondelinge opzegging van een v.o.f.-overeenkomst centraal stond.

45. lets waar de Hoge Raad een voorkeur voor lijkt te hebben; zie o.a. HR 20 december 2013, ECLI:NL:HR:2013:2123 (BP/Benschop); HR 13 juni 2014, ECLI:NL:HR:2014:1385 (Lindorff/Statia).
Een bepaling die duidelijkheid en begrijpelijkheid voorschrijft voor algemene voorwaarden die business-tobusiness worden gebruikt, zou het Burgerlijk Wetboek verrijken. 